\title{
Absence of Mycobacterium avium subspecies paratuberculosis Components from Crohn's Disease Intestinal Biopsy Tissues
}

\author{
*Jay L.E. Ellingson, PhD, Department of Veterinary Pathology, College of Veterinary Medicine, lowa State University, Ames, lowa and the Center for \\ Veterinary Biologics Laboratory, Veterinary Services, Animal and Plant Health Inspection Service, United States Department of Agriculture, Ames, Iowa \\ John C. Cheville, MD, Mayo Clinic, Rochester, Minnesota \\ †Dominique Brees, DVM, PhD, DACVP, Department of Veterinary Pathology, College of Veterinary Medicine, lowa State University, Ames, lowa \\ Janice M. Miller, DVM, PhD, Zoonotic Diseases Research Unit, National Animal Disease Center, Agricultural Research Service, \\ United States Department of Agriculture, Ames, lowa \\ Norman F. Cheville, DVM, PhD, DrHc, Department of Veterinary Pathology, College of Veterinary Medicine, Iowa State University, Ames, Iowa \\ ${ }^{*}$ Current affiliation Marshfield Clinic Laboratories-Food Safety Services, Marshfield Clinic, Marshfield, Wisconsin \\ $\dagger$ Current affiliation Pfizer, Inc., Groton, Connecticut
}

\begin{abstract}
BACKGROUND

Crohn's disease is a chronic human intestinal inflammatory disorder for which an etiologic agent has not been identified. Johne's disease is a similar chronic enteric granulomatous disease of ruminant species and has been used as a model of Crohn's disease. Johne's disease has been proven to be caused by Mycobacterium avium subspecies paratuberculosis

(M. avium ss paratuberculosis). It has been proposed that $M$. avium ss paratuberculosis may also cause Crohn's disease.

This is of particular concern because the organism may be spread to humans through inadequately pasteurized dairy products. OBJECTIVE

We sought to determine whether $M$. avium ss paratuberculosis could be detected using identical techniques in paraffinembedded tissue samples of bovine Johne's disease and human Crohn's, ulcerative colitis and diverticular diseases. Samples were obtained for analysis from national tissue banks.

DESIGN

Cross-species and cross-disease sample comparisons by multiple detection techniques.

METHODS

Histology, immunocytochemistry and polymerase chain reaction (PCR) were utilized to test and compare the presence of

M. avium ss paratuberculosis components. Insertion sequence IS900, present in multiple copies and found only in

M. avium ss paratuberculosis, was utilized in both PCR and immunocytochemical analyses.

RESULTS

The IS900 sequence was demonstrable in all samples of confirmed positive Johne's disease tissue. The sequence was not identified in the 35 Crohn's, 36 ulcerative colitis, and 21 diverticular disease samples.

CONCLUSION

M. avium ss paratuberculosis was not associated with the lesions in these Crohn's disease samples, using these methods.
\end{abstract}

RECEIVED: JUNE 10, 2003

REPRINT REQUESTS:

Jay L.E. Ellingson, PhD

Marshfield Clinic Laboratories

Food Safety Services

Marshfield Clinic

1000 North Oak Avenue

Marshfield, WI 54449

Telephone: $715-389-5958$

Fax: 715-389-7599

Email: ellingson.jay@marshfieldclinic.org
REVISED AND ACCEPTED: JULY 1, 2003

\section{KEYWORDS:}

Crohn's disease; Johne's disease; Inflammatory bowel disease; Mycobacterium avium subspecies paratuberculosis; IS900;

Polymerase chain reaction

GRANT SUPPORT:

USDA grant 1999-038181. 


\section{INTRODUCTION}

Crohn's disease is a chronic inflammatory disorder of the human intestine characterized by protein losing enteropathy, general malabsorption and steatorrhea. Lesions that begin as mucosal erosions and neutrophil infiltrates within crypts and crypt abscesses, progress to transmural lymphogranulomatous enteritis with lymphocyte populations being predominantly $\mathrm{T}_{\mathrm{H}} 1$ cells. $^{1-3} \mathrm{In}$ approximately $50 \%$ of the cases, lymphoid aggregates contain noncaseating granulomas composed of epithelioid histiocytes and multinucleate giant cells of the Langhan's type. Ulcers both discrete and serpiginous, are hallmarks of Crohn's lesions. ${ }^{4}$ Neutrophils and eosinophils are prominent in many lesions, as are plasmacytes bearing IgG, IgM, IgA or IgD. These inflammatory processes underlie the characteristic cobblestone appearance of the mucosal surface.

The cause and some critical aspects in the pathogenesis of human Crohn's disease are not known. Suggestions that the etiological agent involves mycobacteria ${ }^{5,6}$ have been based on the detection of mycobacterial species in intestinal biopsy tissue from Crohn's disease patients including: Mycobacterium avium-intracellulare, Mycobacterium cheloni, Mycobacterium fortuitum, Mycobacterium kansasii, Mycobacterium avium subspecies paratuberculosis (M. avium ss paratuberculosis). ${ }^{5}$

Like human Crohn's disease, Johne's disease of cattle is a chronic, progressive lymphogranulomatous process with preference for the terminal ileum and ileocecal valve. Unlike Crohn's disease, acid-fast intracellular bacilli are always present in lesions, there is no ulceration and the causal bacterium, M. avium ss paratuberculosis, can be isolated. Early in the disease process there is marked edema and lymphangitis at the edge of the expanding enteric lesion. Enteric lesions in Johne's disease are infiltrated with M. avium ss paratuberculosis infected macrophages. Lesions spread and grow by accumulation, reinfection and expansion of macro-phage populations in the intestinal wall. M. avium ss paratuberculosis disseminate from infected to noninfected macro-phages, allowing the bacterium to avoid humoral and cellular mechanisms of immunity. Transmission of $M$. avium ss paratuberculosis among cattle is by ingestion from milk or feces and by placental infection. Chronic infiltration of macrophages in the lamina propria throughout the lower intestine results in villous atrophy and malabsorption. Although infection is often restricted to the intestine, bacteria can spread via monocytes from the primary site of infection in the intestine to liver, spleen, kidney, uterus and mammaries through hematogenous or lymphatic routes.

Due to the clinical symptoms of Crohn's disease closely mimicking those found in animals with Johne's disease, it was proposed almost 90 years ago that the two diseases shared the same etiology. ${ }^{7,8}$ Specifically, M. avium ss paratuberculosis continues to be suspected as the causative agent of both disorders. However, reviews of Johne's disease and its connection to human Crohn's have not established any connection. $6,9-12$
There is no sound epidemiological evidence that links exposure to $M$. avium ss paratuberculosis to an increased incidence of Crohn's disease, even though cows with clinical paratuberculosis do shed viable organisms in their milk at low levels (50 CFU/50 ml milk). ${ }^{13}$ In Great Britain it has been demonstrated that $M$. avium ss paratuberculosis DNA is present in milk samples obtained from retail markets. ${ }^{14}$ Viable $M$. avium ss paratuberculosis have been cultured from the pasteurized retail milk samples. These results suggest that current pasteurization techniques may not be adequate to kill $M$. avium ss paratuberculosis in raw milk, or that milk may become contaminated post pasteurization. Because of the potential for spreading M. avium ss paratuberculosis through widely consumed dairy products, it has become crucial to definitively establish whether or not this organism is actually involved in the etiology of Crohn's diseases.

In recent serologic studies, up to $83 \%$ of Crohn's patients showed evidence of serum antibodies to M. avium ss paratuberculosis. ${ }^{15-20}$ Recently it has been demonstrated that lactating mothers with Crohn's disease shed M. avium ss paratuberculosis in their breast milk. ${ }^{21}$ However, unlike the case for Johne's disease, reports are mixed as to the presence or absence of M. avium ss paratuberculosis at the site of the intestinal lesions.

Studies that used genetic primers in polymerase chain reaction (PCR) analyses to detect the organism in Crohn's patient tissues have yielded the most provocative data. ${ }^{22-28}$ The most widely used primers are for insertion sequence 900 (IS900), a genetic element proven to be quite specific for $M$. avium ss paratuberculosis. ${ }^{29-32}$ In those studies, from $13 \%$ to $100 \%$ of Crohn's patients tested positive for M. avium ss paratuberculosis by IS900 DNA/PCR. ${ }^{33-44}$ Other studies, however, have been unable to demonstrate M. avium ss paratuberculosis DNA in Crohn's disease tissue. ${ }^{5,11,12,45-50}$ One potential problem with these results is that some primers designed from IS 900 can cross-react with closely related IS901 and IS902.51-55

It is therefore crucial to use primers that are very sensitive and specific to the $M$. avium ss paratuberculosis organism. In this study we used the specific IS900 primers in PCR analyses to search for evidence of $M$. avium ss paratuberculosis-infection in formalin-fixed, paraffin-embedded tissue sections from bovine Johne's disease and human Crohn's disease, ulcerative colitis and diverticular disease. For comparison the more widely used immunohistochemistry was applied. This was compared to the PCR analyses of a DNA insertion sequence that allows for specific identification of DNA from M. avium ss paratuberculosis. The IS900 sequence was demonstrable in all samples of confirmed positives of Johne's disease tissue. The sequence was not identified in the 35 Crohn's, 36 ulcerative colitis, and 21 diverticular disease samples. The evidence does not support the involvement of $M$. avium ss paratuberculosis in the etiology of Crohn's disease. 


\section{METHODS}

Tissue samples

A retrospective sample from a large individual collection of human Crohn's, ulcerative colitis and diverticular disease, was obtained from the Department of Pathology at Mayo Clinic. Additionally, samples of confirmed bovine Johne's disease from the United States Department of Agriculture were obtained and examined. Tissue sections were formalinfixed, paraffin-embedded and processed by standard procedures via standard operating protocols from both the Department of Pathology, Mayo Clinic and the National Veterinary Services Laboratory, Animal and Plant Health Inspection Service, United States Department of Agriculture. ${ }^{56,57}$ Samples were screened for colonic lesions that showed clear evidence of granulomas. These samples were then analyzed by immunohistochemistry and transmission electron microscopy for cytologic characteristics of affected macrophages, and lymphoid and vascular cells at the margins of the progressive granulomatous lesions.

\section{Immunohistochemistry}

An immunohistochemical technique to specifically detect M. avium ss paratuberculosis has been developed to detect antigens of $M$. avium ss paratuberculosis in formalin-fixed, paraffin-embedded tissue sections. ${ }^{58}$ The probe detected M. avium ss paratuberculosis in infected bovine tissues. Tissue sections from animals infected with M. avium ss avium were negative. Thus, differentiation between M. avium ss paratuberculosis and M. avium ss avium in formalin-fixed, paraffin-embedded bovine tissues was possible. ${ }^{58}$

\section{Identification of mycobacteria}

Procedures used to cut paraffin-embedded tissue sections and prepare crude DNA extracts have been previously described. ${ }^{56,57}$ Ten microliter aliquots of each crude extract were tested with each set of PCR primers (table 1). Samples that failed to react with any primer were retested using purified DNA. The DNA purification procedure was modified slightly from the original. ${ }^{47,56}$ The $10 \mu \mathrm{l}$ aliquots were used for all PCR amplifications.

\section{PCR}

Each sample was examined with a PCR primer set derived from IS900, as previously described. ${ }^{56}$ IS 900 characteristically is present in multiple copies and is considered specific for M. avium ss paratuberculosis. ${ }^{56,62,71}$

All amplification reactions were conducted with a "Hot Start" procedure that is based on heat-activated polymerase, as previously described. The concentration of reactants $(50 \mu \mathrm{l}$ final volume) was as follows: $20 \mathrm{pM}$ primers, $1.25 \mathrm{U}$ DNA polymerase, $0.2 \mathrm{mM}$ nucleotides, and $2.5 \mathrm{mM} \mathrm{Mg}^{++}$. Each set of test samples included a negative control tube in which water was substituted for a test sample. A complete mastermix was prepared for the IS 900 primer set. The $40 \mu \mathrm{L}$ aliquots were introduced into the reaction tubes which were held at $-70^{\circ} \mathrm{C}$ until use. Positive control DNA (10 ng) was obtained from bacterial culture extracts and from sections cut from paraffin-embedded tissue of confirmed Johne's disease.

Amplification conditions for the IS900 primers were as follows: 10 minutes at $94^{\circ} \mathrm{C}$, then 1 minute at $94^{\circ} \mathrm{C}, 15$ seconds at $65^{\circ} \mathrm{C}$, and 2 minutes at $72^{\circ} \mathrm{C}$ for 50 cycles, and a final 10 minute extension at $72^{\circ} \mathrm{C}$.

\section{RESULTS}

\section{Histology and immunohistochemistry}

Macrophages and multinucleate giant cells in granulomas in Crohn's biopsies did not contain bacilli; there was no evidence of other bacteria, fungi or viruses in tissues stained using acid-fast Stain (auramine-rhodamine) ${ }^{59}$ and gram stains. There was no ultrastructural evidence of intracellular bacterial replication; e.g., cells lacked bacteriophorous vacuoles, well-developed Golgi complexes and vacuolar transport systems. In three cases of Crohn's disease, acidfast material was present, but by electron microscopy this material was shown to be cellular debris, not bacilli. No acid-fast bacilli were detected within enteric lesions of tissues from ulcerative colitis or from diverticular disease.

Intestines of Johne's disease were composed of three hallmark lesions: transmural masses of relatively uniform populations of large macrophages bearing many small, acid-fast bacilli; lymphangitis with dilation of lymphatic vessels in lamina propria of the villus, muscularis mucosa and submucosa; and marginal zones of lymphocyte-monocyte/macrophage infiltrates at the advancing edge of the submucosal lesion (figure 1).

The latter was composed of interstitial edema, lymphangitis, lymphoplasmacytic perivascularitis, and lymphoid cells, many of which were associated with infected macrophages. Lymphocytes with close apposition to infected macrophages had chromatin aggregates, ruffled surfaces and pale cytoplasm typical of apoptosis (figure 2). Bacilli in Johne's disease lesions stained strongly with auramine, acridine orange and by electron microscopy, had ultrastructural characteristics of Mycobacterium spp. Ultrastructurally, macrophages in the granulomatous response had high cytoplasmic-nuclear volume ratios, with a great part of the cytoplasm mass being bacteriophorous vacoules and intact bacilli.

Table 1. IS900 oligonucleotide primers used for PCR amplification of $M$. avium ss paratuberculosis.

\begin{tabular}{cccc}
\hline Organism & Primer & PCR Product (bp) & Sequence \\
\hline M. avium ss. paratuberculoisis & IS900 & 229 & CCGCTAATTGAGAGATGCGATTGG \\
& & & AATCAACTCCAGCAGCGCGGCCTCG \\
\hline
\end{tabular}




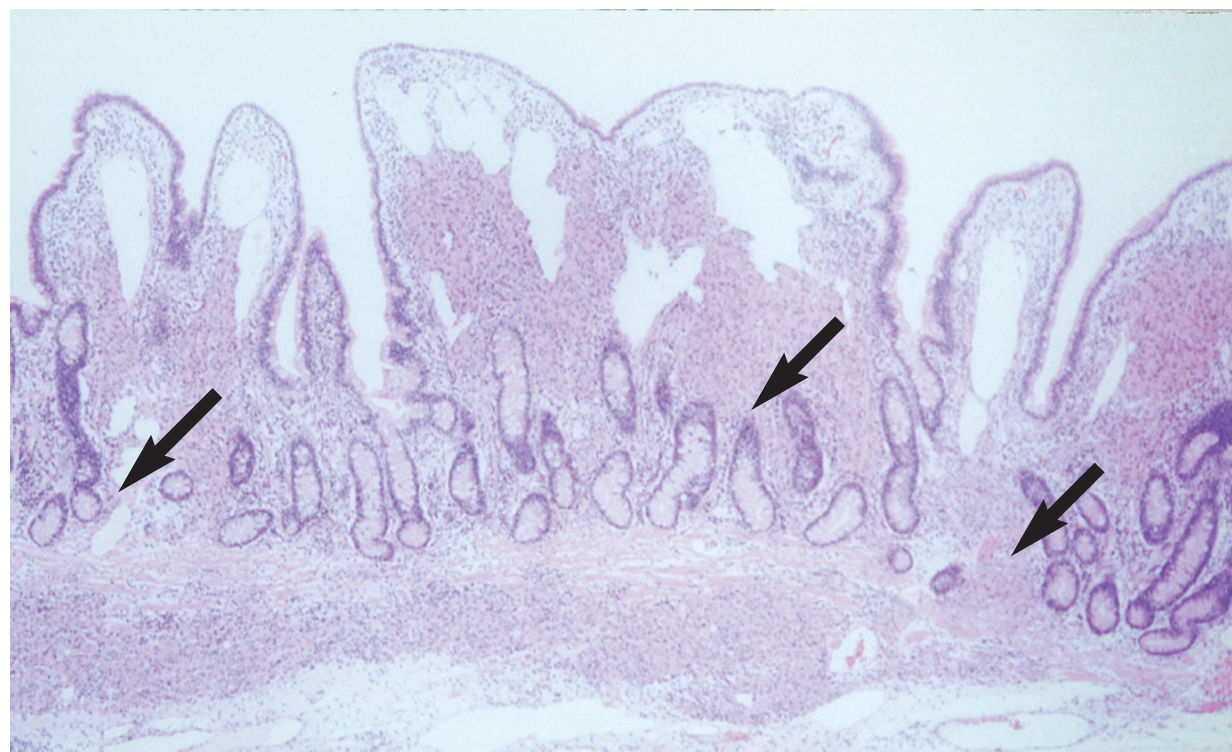

Figure 1. Transmural granulomatous lesion in the intestine, cow, Johne's disease. Villi of the ileal mucosa are atrophic and fused, and masses of macrophages separate glands, efface the muscularis mucosa and infiltrate the submucosa. There is marked dilation of submucosal lymphatic vessels (see arrows).

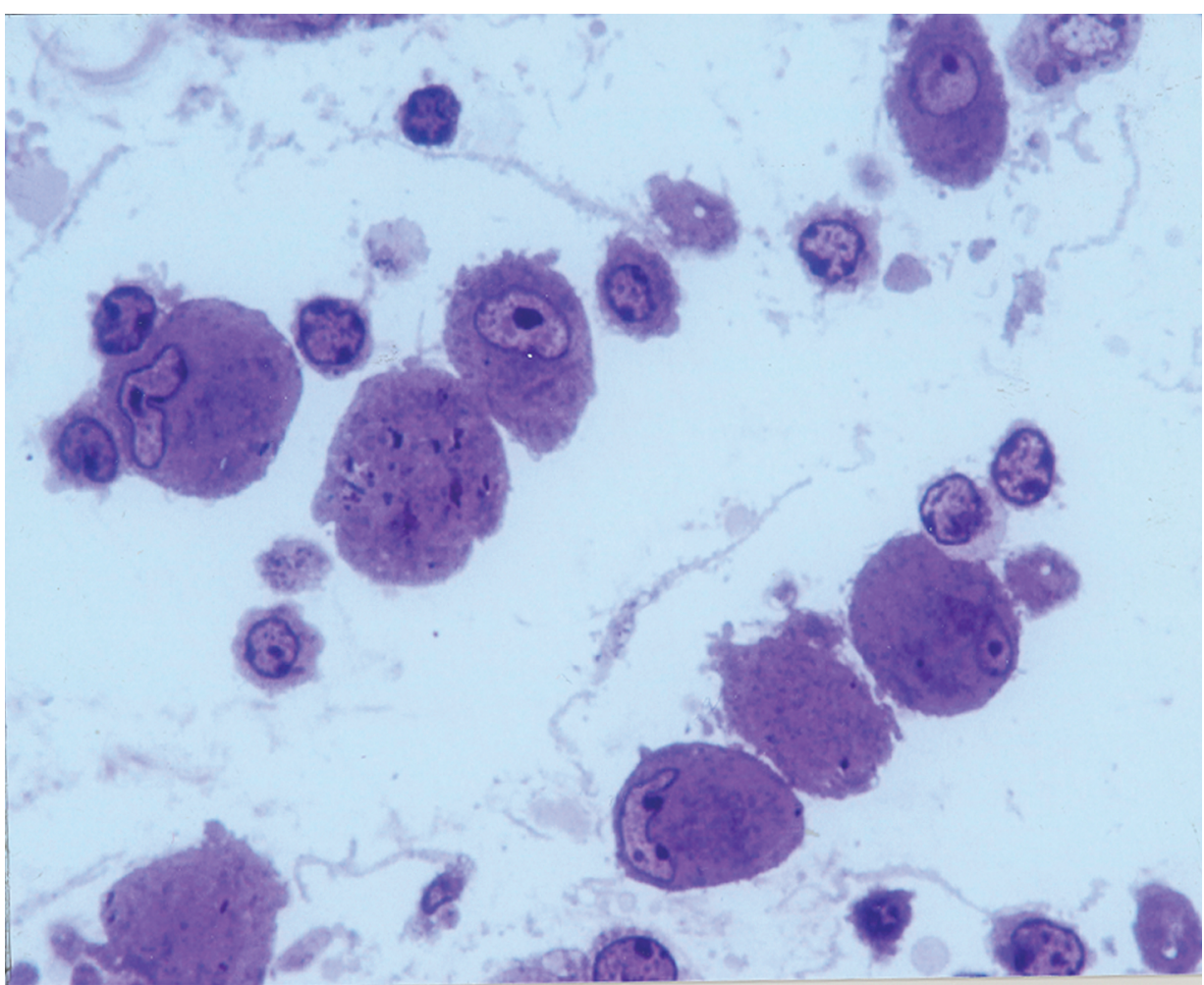

Figure 2. Submucosa from tissue adjacent to that of figure 1. Advancing edge of submucosal granulomatous lesions with evidence of edema, lymphatic dilation. Large activated monocytes, macrophage-lymphocyte interaction and lymphangitis. Lymphocyte closely apposed to infected macrophage has evidence of apoptosis. 


\section{PCR}

The IS900 PCR analysis is purportedly specific for M. avium ss paratuberculosis. It is very sensitive and specific for $M$. avium ss paratuberculosis, displaying no cross-reactivity. The IS900 sequence was demonstrable in all samples of bovine Johne's disease tissue. The sequence was not identified in the Crohn's (35), ulcerative colitis (36), and diverticular disease (21) samples (example set, figure 3). However, three Crohn's disease reactions were suspicious, yielding abnormal sized PCR products (data not shown). These abnormal sized PCR products were very weak bands using purified DNA, and they failed to give a product upon reamplification. It was suspected that these bands may have been the result of minor contamination or nonspecific annealing products. Three ulcerative colitis samples yielded much larger sized bands than expected. However, based on our specific criteria they were considered negative. These samples were confirmed negative upon reamplification.

\section{DISCUSSION}

M. avium ss paratuberculosis in not associated with the lesions in these Crohn's disease samples using these methods. This study represents the first direct comparison of PCR analyses from both Crohn's and Johne's tissues. It utilizes specific primers from IS900. At this time we believe that Crohn's disease and Johne's disease have separate and distinct etiologies. Importantly, these results should also assuage concern over the spread of Crohn's disease to susceptible populations via the consumption of $M$. avium ss paratuberculosis-contaminated dairy products. ${ }^{63-68}$

Previous studies have reported the isolation of $M$. avium ss paratuberculosis from colonic tissue, $38,40,48,60,61$ the detection of M. avium ss paratuberculosis DNA by PCR of IS900 in suspensions of colonic tissues, $33,41,62,69$ in paraffinembedded tissue sections $35,37,45,70,71$ and the presence of serum antibodies against $M$. avium ss paratuberculosis in Crohn's patients. ${ }^{15-20}$ However, none of these studies purport to detect evidence of $M$. avium ss paratuberculosis in all Crohn's tissues sampled. In fact, the occurrence rate is often quite low. This contrasts sharply with the association of M. avium ss paratuberculosis with bovine Johne's disease. ${ }^{70}$ The low incidence rates in Crohn's tissues may be more of a reflection of the widespread occurrence of mycobacterial organisms, than an indication that $M$. avium ss paratuberculosis is a causative agent in Crohn's disease.

IS900 has been considered to be the most selective primer set for M. avium ss paratuberculosis. Although some previously used IS900 PCR primer have exhibited crossreactivity with IS901, a closely related M. avium ss avium specific insertion element, thus opening the possibility that some positive reports might also be attributed to $M$. avium subspecies other than paratuberculosis.

In contrast the IS900 specific primers used in this study have exhibited no cross-reactivity in extensive screenings with hundreds of organisms in the American Type Culture Collection (http://www.atcc.org/). It may thus be considered to be the most specific and sensitive primer set for $M$. avium ss paratuberculosis available to date.

Due to the specificity and sensitivity of the IS900 primer set and the dramatic difference seen between the presence of M. avium ss paratuberculosis in Johne's tissues and Crohn's tissues, we feel that this organism is not directly involved in the granulomatous responses of Crohn's disease.

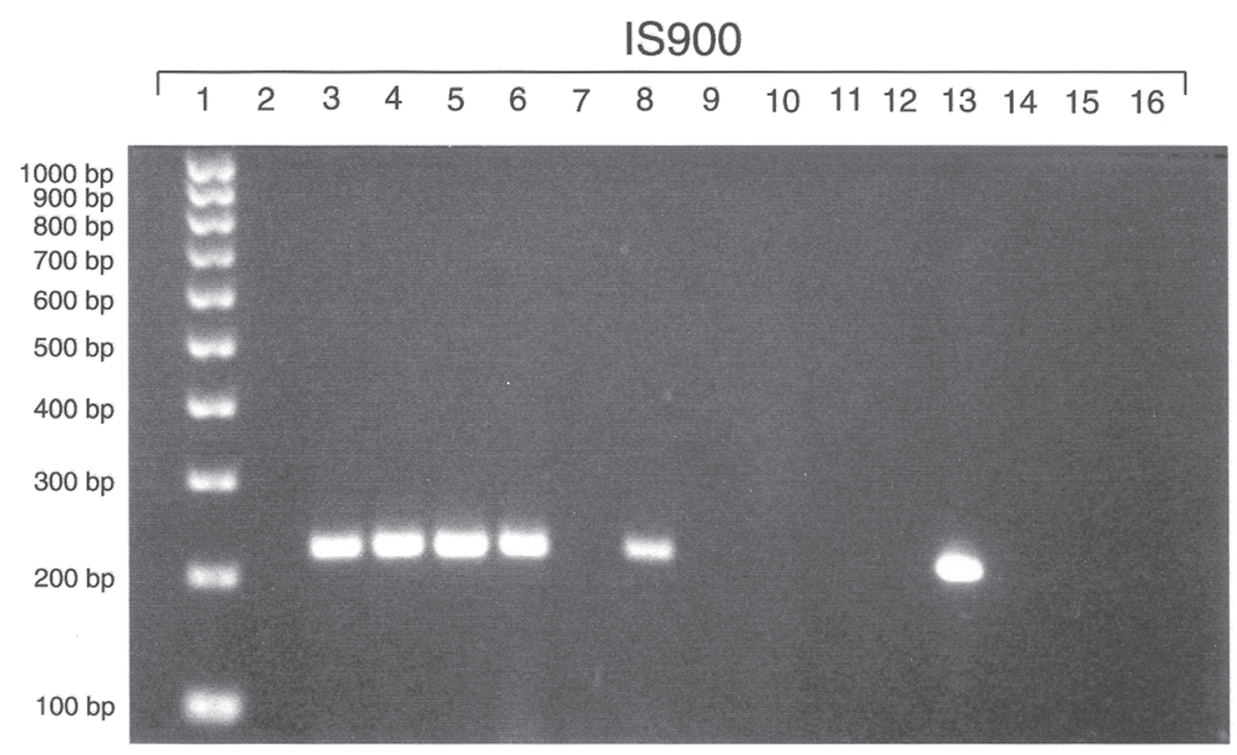

Figure 3. IS900 specific PCR amplification of crude DNA extracts from paraffin-embedded tissue sections from human Crohn's, human ulcerative colitis, human diverticular disease, and animal culture positive cases of $M$. avium ss paratuberculosis infection. Lanes are as follows: Lane 1: molecular size markers; Lanes 2, 7, 16: reagent control (as template added); Lanes 3-6: bovine tissues; Lane 8: bison tissue; Lanes 9 and 10: human Crohn's; Lanes 11 and 12: human ulcerative colitis; Lane 13: purified positive $M$. avium ss paratuberculosis control DNA from culture extract; Lanes 14 and 15: human diverticular disease. 
Other evidence lends credence to this conclusion. Prior to this, there has been no clinical evidence that unequivocally shows an increased incidence of Crohn's disease in farmers or agricultural workers associated with dairy herds with a high incidence of Johne's disease. Nor has eating organs or tissues from infected animals been documented to cause infection of humans with M. avium ss paratuberculosis. Subclinically infected animals harbor the organisms in the lower small intestine and the regional lymph nodes, making them an unlikely source of infection for consumers. However, M. avium ss paratuberculosis can be widely disseminated in the latter stages of clinical disease, with viable organisms present in the liver, spleen, kidneys, lungs, pancreas, thymus gland, uterus and epicardium. ${ }^{72}$ Consumption of these organs by humans might transmit the organism, even though no infection occurs. No published information is available to date on whether M. avium ss paratuberculosis can be cultured from muscle tissue of infected cows.

The most worrisome avenue of potential spread of $M$. avium ss paratuberculosis to humans is thought to be through the consumption of inadequately pasteurized dairy products. Standard temperatures and times for heat pasteurization of milk, especially either via standard holder methods $\left(63.5^{\circ} \mathrm{C}\right.$ for 30 minutes) or high-temperature, short-time methods ( $71.7^{\circ} \mathrm{C}$ for 15 seconds), have been shown to be insufficient to kill all M. avium ss paratuberculosis in milk. ${ }^{73,74}$ Studies of raw milk inoculated with live $M$. avium ss paratuberculosis $(104,106 \mathrm{CFU} / \mathrm{ml})$, have demonstrated that it is possible to effectively kill all the bacteria using laboratory-scale pasteurizers $\left(72^{\circ} \mathrm{C}\right.$ for 15 seconds). ${ }^{43} \mathrm{~A}$ group in Australia has further corroborated this data in a study using a smallscale commercial pasteurizing unit. ${ }^{75}$ These studies indicate the transmission of viable $M$. avium ss paratuberculosis from animals to humans via adequately pasteurized dairy products can be made even less likely, thus minimizing any remaining potential concern that it may act as a zoonotic agent in Crohn's disease.

Additionally, M. avium ss paratuberculosis has been reported to cause Johne's disease only in a variety of ungulate species. No non-ruminant animals have been found to be affected. Aside from the dramatic differences between ruminant and non-ruminant gastrointestinal physiologies, an explanation for this difference has not yet been forwarded.

Finally, human Crohn's disease may prove to be an immunitymediated susceptibility to general bacterial infections in the gastrointestinal mucosa. A gene associated with susceptibility to Crohn's disease has now been identified. CARD15/NOD2 situated within the IBD1 region of chromosome 16q12,76-79 is only expressed in monocytes and macrophages. CARD15 encodes a protein composed of two caspase recruitment domains, a nucleotide-binding domain and leucine-rich repeats. ${ }^{80,81}$ The caspase recruitment domains enable a protein to induce apoptosis and the NF- $\kappa \mathrm{B}$ signaling pathways. $C A R D 15$ has been proposed to be an intracellular receptor for bacterial components in monocytes where it is mainly expressed. ${ }^{80}$ Leucine-rich repeats are involved in the interaction with the lipopolysaccharides of infecting bacteria. ${ }^{82}$ Three main mutations of CARD15 have been found in patients with Crohn's disease, but not in patients with ulcerative colitis. All occur in the leucine-rich repeats domain or its vicinity. ${ }^{76,77,83}$ Thus these mutations may alter the recognition of the bacterial lipopolysaccharides. Other rare variants also occur. ${ }^{81,83}$

However, this is not yet the complete mechanism. Crohn's may be stratified into ileal, colonic and perianal fistular. It has been independently demonstrated by two groups that the CARD15/NOD2 mutations are seen only in the cases restricted to ileal Crohn's disease. ${ }^{84-86}$ It has been speculated that gut bacteria occur at much higher concentrations in the colon than in the ileum. Therefore additional mechanisms to combat higher levels of bacteria have evolved in the colon, whereas the ileum may be more dependent on the function of NOD2. ${ }^{84}$ Other mutations are actively being sought, especially in the interleukin and major histocompatibility complex regions. ${ }^{87-89}$

M. avium ss paratuberculosis is resilient in the environment and is relatively ubiquitous. It is likely that $M$. avium ss paratuberculosis may commonly or transiently exist in the intestinal tract of the normal population. ${ }^{16,27}$ In light of the new genetic findings, it seems likely that patients with Crohn's disease have an altered immune reaction against M. avium ss paratuberculosis and a variety of other intestinal microorganisms. Some patient populations may be exposed to M. avium ss paratuberculosis, while others are not, and in the latter group some other offending organism triggers the aberrant immune response in the intestinal wall. Our patient population showed no evidence of $M$. avium ss paratuberculosis infection. However, this study accurately confirmed an already established association between $M$. avium ss paratuberculosis and Johne's disease lesions in ruminants, no etiology of Crohn's disease was determined.

\section{ACKNOWLEDGMENTS}

The authors thank Marshfield Clinic Research Foundation for its support through the assistance of Alice Stargardt and Graig Eldred in the preparation of this manuscript. 


\section{REFERENCES}

1. Desreumaux P, Brandt E, Gambiez L, Emilie D, Geboes K, Klein O, Ectors N, Cortot A, Capron M, Colombel JF. Distinct cytokine patterns in early and chronic ileal lesions of Crohn's disease. Gastroenterology 1997;113:118-126.

2. Fuss IJ, Neurath M, Boirivant M, Klein JS, de la Motte C, Strong SA, Fiocchi C, Strober W. Disparate CD4+ lamina propria (LP) lymphokine secretion profiles in inflammatory bowel disease. Crohn's disease LP cell manifest increased secretion of IFN-gamma, whereas ulcerative colitis LP cells manifest increased secretion of IL-5. J Immunol 1996;157:1261-1270.

3. Parronchi P, Romagnani P, Annunziato F, Sampognaro S, Becchio A, Giannarini L, Maggi E, Pupilli C, Tonelli F, Romagnani S. Type $1 \mathrm{~T}$-helper cell predominance and interleukin-12 expression in the gut of patients with Crohn's disease. Am J Pathol 1997;150:823-832.

4. Hamilton SR, Morson BC. Crohn's disease. Part 1: Pathology. In: Haubrich WS, Schaffner F, Berk JE, Bockus HL (Eds). Bockus gastroenterology, Volume 2. Philadelphia, W.B. Saunders, 1995, pp 1398-1409.

5. Chiodini RJ. Crohn's disease and the mycobacterioses: a review and comparison of two disease entities. Clin Microbiol Rev 1989;2:90-117.

6. Thompson DE. The role of mycobacteria in Crohn's disease. J Med Microbiol 1994, 41:74-94.

7. Dalziel TK. Chronic intestinal enteritis. Br Med J 1913;ii:1068-1070.

8. Crohn BB, Ginzburg L, Oppenheimer GD. Regional ileitis; a pathologic and clinical entity. JAMA 1932;99:1323-1329.

9. Engstrand L. Mycobacterium paratuberculosis and Crohn's disease. Scand J Infect Dis Suppl 1995;98:27-29.

10. Erasmus DL, Victor TC, Van Eeden PJ, Falck V, Van Helden P. Mycobacterium paratuberculosis and Crohn's disease. Gut 1995;36:942.

11. Quirke P. Antagonist. Mycobacterium avium subspecies paratuberculosis is a cause of Crohn's disease. Gut 2001;49:757-760.

12. Van Kruiningen HJ. Lack of support for a common etiology in Johne's disease of animals and Crohn's disease in humans. Inflamm Bowel Dis 1999;5:183-191.

13. Sweeney RW, Whitlock RH, Rosenberger AE. Mycobacterium paratuberculosis cultured from milk and supramammary lymph nodes of infected asymptomatic cows. J Clin Microbiol 1992;30:166-171.

14. Millar D, Ford J, Sanderson J, Withey S, Tizard M, Doran T, Hermon-Taylor J. IS900 PCR to detect Mycobacterium paratuberculosis in retail supplies of whole pasteurized cows' milk in England and Wales. Appl Environ Microbiol 1996;62:3446-3452.

15. Elsaghier A, Prantera C, Moreno C, Ivanyi J. Antibodies to Mycobacterium paratuberculosis-specific protein antigens in Crohn's disease. Clin Exp Immunol 1992;90:503-508.

16. Suenaga K, Yokoyama Y, Nishimori I, Sano S, Morita M, Okazaki K, Onishi S. Serum antibodies to Mycobacterium paratuberculosis in patients with Crohn's disease. Dig Dis Sci 1999;44:1202-1207.

17. Naser S, Shafran I, El-Zaatari F. Mycobacterium avium subsp. paratuberculosis in Crohn's disease is serologically positive. Clin Diagn Lab Immunol 1999;6:282.
18. Naser SA, Hulten K, Shafran I, Graham DY, El-Zaatari FA. Specific seroreactivity of Crohn's disease patients against p35 and p36 antigens of M. avium subsp. paratuberculosis. Vet Microbiol 2000;77:497-504.

19. Olsen I, Wiker HG, Johnson E, Langeggen H, Reitan LJ. Elevated antibody responses in patients with Crohn's disease against a $14-\mathrm{kDa}$ secreted protein purified from Mycobacterium avium subsp. paratuberculosis. Scand J Immunol 2001;53:198-203.

20. El-Zaatari FA, Naser SA, Hulten K, Burch P, Graham DY. Characterization of Mycobacterium paratuberculosis $\mathrm{p} 36$ antigen and its seroreactivities in Crohn's disease. Curr Microbiol 1999;39:115-119.

21. Naser SA, Schwartz D, Shafran I. Isolation of Mycobacterium avium subsp. paratuberculosis from breast milk of Crohn's disease patients. Am J Gastroenterol 2000;95:1094-1095.

22. El-Zaatari FA, Osato MS, Graham DY. Etiology of Crohn's disease: the role of Mycobacterium avium paratuberculosis. Trends Mol Med 2001;7:247-252.

23. Hermon-Taylor J, Bull TJ, Sheridan JM, Cheng J, Stellakis ML, Sumar N. Causation of Crohn's disease by Mycobacterium avium subspecies paratuberculosis. Can J Gastroenterol 2000;14:521-539.

24. Hermon-Taylor J. Protagonist. Mycobacterium avium subspecies paratuberculosis is a cause of Crohn's disease. Gut 2001;49:755-756.

25. Hulten K, El-Zimaity HM, Karttunen TJ, Almashhrawi A, Schwartz MR, Graham DY, El-Zaatari FA. Detection of Mycobacterium avium subspecies paratuberculosis in Crohn's diseased tissues by in situ hybridization. Am J Gastroenterol 2001;96:1529-1535.

26. Sechi LA, Mura M, Tanda F, Lissia A, Solinas A, Fadda G, Zanetti S, Manuela M, Francesco T, Amelia L, Antonello S, Giovanni F, Stefania Z. Identification of Mycobacterium avium subsp. paratuberculosis in biopsy specimens from patients with Crohn's disease identified by in situ hybridization. J Clin Microbiol 2001;39:45144517.

27. Chamberlin W, Graham DY, Hulten K, El-Zimaity HM, Schwartz MR, Naser S, Shafran I, El-Zaatari FA. Review article: Mycobacterium avium subsp. paratuberculosis as one cause of Crohn's disease. Aliment Pharmacol Ther 2001; 15:337-346.

28. Ikonomopoulos JA, Gorgoulis VG, Kastrinakis NG, Zacharatos PV, Kokotas SN, Evangelou K, Kotsinas AG, Tsakris AG, Manolis EN, Kittas CN. Sensitive differential detection of genetically related mycobacterial pathogens in archival material. Am J Clin Pathol 2000;114:940-950.

29. Hulten K, Karttunen TJ, El-Zimaity HM, Naser SA, Almashhrawi A, Graham DY, El-Zaatari FA. In situ hybridization method for studies of cell wall deficient $M$. paratuberculosis in tissue samples. Vet Microbiol 2000;77:513-518.

30. Hulten K, Karttunen TJ, El-Zimaity HM, Naser SA, Collins MT, Graham DY, El-Zaatari FA. Identification of cell wall deficient forms of M. avium subsp. paratuberculosis in paraffin embedded tissues from animals with Johne's disease by in situ hybridization. J Microbiol Methods 2000;42:185-195. 
31. Schwartz D, Shafran I, Romero C, Piromalli C, Biggerstaff J, Naser N, Chamberlin W, Naser SA. Use of short-term culture for identification of Mycobacterium avium subsp. paratuberculosis in tissue from Crohn's disease patients. Clin Microbiol Infect 2000;6:303-307.

32. Tiveljung A, Soderholm JD, Olaison G, Jonasson J, Monstein HJ. Presence of eubacteria in biopsies from Crohn's disease inflammatory lesions as determined by 16S rRNA gene-based PCR. J Med Microbiol 1999;48:263-268.

33. Dell'Isola B, Poyart C, Goulet O, Mougenot JF, SadounJourno E, Brousse N, Schmitz J, Ricour C, Berche P. Detection of Mycobacterium paratuberculosis by polymerase chain reaction in children with Crohn's disease. J Infect Dis 1994;169:449-451.

34. Dubos RJ, Middlebrook G. The effect of wetting agents on the growth of tubercle bacilli. J Exp Med 1948;88:81-89.

35. Fidler HM, Thurrell W, Johnson NM, Rook GA, McFadden JJ. Specific detection of Mycobacterium paratuberculosis DNA associated with granulomatous tissue in Crohn's disease. Gut 1994;35:506-510.

36. Hermon-Taylor J. Mycobacterium paratuberculosis as a chronic enteric pathogen in humans. In: Chiodini RJ, Collins MT, Bassey EOE (Eds). Proceedings of the Fourth International Colloquium on Paratuberculosis, 1995, pp 388-394.

37. Lisby G, Andersen J, Engbaek K, Binder V. Mycobacterium paratuberculosis in intestinal tissue from patients with Crohn's disease demonstrated by a nested primer polymerase chain reaction. Scand J Gastroenterol 1994;29:923-929.

38. McFadden J, Collins J, Beaman B, Arthur M, Gitnick G. Mycobacteria in Crohn's disease: DNA probes identify the wood pigeon strain of Mycobacterium avium and Mycobacterium paratuberculosis from human tissue. J Clin Microbiol 1992;30:3070-3073.

39. Mishina D, Katsel P, Brown ST, Gilberts EC, Greenstein RJ. On the etiology of Crohn's disease. Proc Natl Acad Sci USA 1996;93:9816-9820.

40. Moss MT, Sanderson JD, Tizard ML, Hermon-Taylor J, elZaatari FA, Markesich DC, Graham DY. Polymerase chain reaction detection of Mycobacterium paratuberculosis and Mycobacterium avium subsp silvaticum in long term cultures from Crohn's disease and control tissues. Gut 1992;33:1209-1213.

41. Murray A, Oliaro J, Schlup MM, Chadwick VS. Mycobacterium paratuberculosis and inflammatory bowel disease: frequency distribution in serial colonoscopic biopsies using the polymerase chain reaction. Microbios 1995;83:217-228.

42. Schaefer WB, Lewis CW Jr. Effect of oleic acid on growth and cell structure of mycobacteria. J Bacteriol 1965;90:1438-1447.

43. Stabel JR, Steadham E, Bolin CA. Heat inactivation of Mycobacterium paratuberculosis in raw milk: are current pasteurization conditions effective? Appl Environ Microbiol 1997;63:4975-4977.

44. Suenaga K, Yokoyama Y, Okazaki K, Yamamoto Y. Mycobacteria in the intestine of Japanese patients with inflammatory bowel disease. Am J Gastroenterol 1995;90:76-80.
45. Frank TS, Cook SM. Analysis of paraffin sections of Crohn's disease for Mycobacterium paratuberculosis using polymerase chain reaction. Mod Pathol 1996;9:3235.

46. Rosenberg WM, Bell JI, Jewell DP. Mycobacterium paratuberculosis DNA cannot be detected in Crohn's disease tissues. Gastroenterology 1991;100:A611.

47. Rowbotham DS, Mapstone NP, Trejdosiewicz LK, Howdle PD, Quirke P. Mycobacterium paratuberculosis DNA not detected in Crohn's disease tissue by fluorescent polymerase chain reaction. Gut 1995;37:660-667.

48. Sanderson JD, Moss MT, Tizard ML, Hermon-Taylor J. Mycobacterium paratuberculosis DNA in Crohn's disease tissue. Gut 1992;33:890-896.

49. Wu SW, Pao CC, Chan J, Yen TS. Lack of mycobacterial DNA in Crohn's disease tissue. Lancet 1991;337:174-175.

50. Kanazawa K, Haga Y, Funakoshi O, Nakajima H, Munakata A, Yoshida Y. Absence of Mycobacterium paratuberculosis DNA in intestinal tissues from Crohn's disease by nested polymerase chain reaction. J Gastroenterol 1999;34:200-206.

51. Ahrens P, Giese SB, Klausen J, Inglis NF. Two markers, IS901-IS902 and p40, identified by PCR and by using monoclonal antibodies in Mycobacterium avium strains. J Clin Microbiol 1995;33:1049-1053.

52. Klausen J, Giese SB, Fuursted K, Ahrens P. Distribution of serotypes, IS901 and a $40 \mathrm{kDa}$ protein in Mycobacterium avium complex strains isolated from man and animals in Denmark. APMIS 1997;105:277-282.

53. Kunze ZM, Portaels F, McFadden JJ. Biologically distinct subtypes of Mycobacterium avium differ in possession of insertion sequence IS901. J Clin Microbiol 1992;30:23662372.

54. Kunze ZM, Wall S, Appelberg R, Silva MT, Portaels F, McFadden JJ. IS901, a new member of a widespread class of atypical insertion sequences, is associated with pathogenicity in Mycobacterium avium. Mol Microbiol 1991;5:2265-2272.

55. Nishimori K, Eguchi M, Nakaoka Y, Onodera Y, Ito T, Tanaka K. Distribution of IS901 in strains of Mycobacterium avium complex from swine by using IS901-detecting primers that discriminate between $M$. avium and Mycobacterium intracellulare. J. Clin Microbiol 1995;33:2102-2106.

56. Miller JM, Jenny AL, Ellingson JL. Polymerase chain reaction identification of Mycobacterium avium in formalinfixed, paraffin-embedded animal tissues. J Vet Diagn Invest 1999;11:436-440.

57. Miller J, Jenny A, Rhyan J, Saari D, Suarez D. Detection of Mycobacterium bovis in formalin-fixed, paraffin-embedded tissues of cattle and elk by PCR amplification of an IS6110 sequence specific for Mycobacterium tuberculosis complex organisms. J Vet Diagn Invest 1997;9:244-249.

58. Brees DJ, Reimer SB, Cheville NF, Florance A, Thoen CO. Immunohistochemical detection of Mycobacterium paratuberculosis in formalin-fixed, paraffin-embedded bovine tissue sections. J Vet Diagn Invest 2000;12:60-63.

59. Mote RF, Muhm RL, Gigstad DC. A staining method using acridine orange and auramine $\mathrm{O}$ for fungi and mycobacteria in bovine tissue. Stain Technol 1975;50:5-9. 
60. Chiodini RJ, Kruiningen HJ, Thayer WR, Coutu JA. Spheroplastic phase of mycobacteria isolated from patients with Crohn's disease. J Clin Microbiol 1986;24:357-363.

61. McFadden JJ, Butcher PD, Chiodini R, Hermon-Taylor J. Crohn's disease-isolated mycobacteria are identical to Mycobacterium paratuberculosis, as determined by DNA probes that distinguish between mycobacterial species. J Clin Microbiol 1987;25:796-801.

62. Wards BJ, Collins DM, de Lisle GW. Detection of Mycobacterium bovis in tissues by polymerase chain reaction. Vet Microbiol 1995;43:227-240.

63. Odumeru J, Gao A, Chen S, Raymond M, Mutharia L. Use of the bead beater for preparation of Mycobacterium paratuberculosis template DNA in milk. Can J Vet Res 2001;65:201-205.

64. Rowan NJ, MacGregor SJ, Anderson JG, Cameron D, Farish O. Inactivation of Mycobacterium paratuberculosis by pulsed electric fields. Appl Environ Microbiol 2001;67:2833-2836.

65. Stabel JR. Johne's disease and milk: do consumers need to worry? J Dairy Sci 2000;83:1659-1663.

66. Bakker D, Willemsen PT, van Zijderveld FG. Paratuberculosis recognized as a problem at last: a review. Vet Q 2000;22:200-204.

67. Hermon-Taylor J, Bull T. Crohn's disease caused by Mycobacterium avium subspecies paratuberculosis: a public health tragedy whose resolution is long overdue. $\mathrm{J}$ Med Microbiol 2002;51:3-6.

68. Harris JE, Lammerding AM. Crohn's disease and Mycobacterium avium subsp. paratuberculosis: current issues. J Food Prot 2001;64:2103-2110.

69. Collins MT, Lisby G, Moser C, Chicks D, Christensen S, Reichelderfer M, Hoiby N, Harms BA, Thomsen OO, Skibsted U, Binder V. Results of multiple diagnostic tests for Mycobacterium avium subsp. paratuberculosis in patients with inflammatory bowel disease and in controls. J Clin Microbiol 2000;38:4373-4381.

70. Vary PH, Andersen PR, Green E, Hermon-Taylor J, McFadden JJ. Use of highly specific DNA probes and the polymerase chain reaction to detect Mycobacterium paratuberculosis in Johne's disease. J Clin Microbiol 1990;28:933-937.

71. Richter E, Schluter C, Duchrow M, Hahn M, Rusch-Gerdes S, Galle J, Flad HD, Gerdes J. An improved method for the species-specific assessment of mycobacteria in routinely formalin-fixed and paraffin-embedded tissues. J Pathol 1995; 175:85-92.

72. Hines SA, Buergelt CD, Wilson JH, Bliss EL. Disseminated Mycobacterium paratuberculosis infection in a cow. J Am Vet Med Assoc 1987;190:681-683.

73. Chiodini RJ, Hermon-Taylor J. The thermal resistance of Mycobacterium paratuberculosis in raw milk under conditions simulating pasteurization. J Vet Diagn Invest 1993;5:629-631.
74.Grant IR, Ball HJ, Neill SD, Rowe MT. Inactivation of Mycobacterium paratuberculosis in cows' milk at pasteurization temperatures. Appl Environ Microbiol 1996;62:631-636.

75. Hope AF, Tulk PA, Condron RJ. Commercial pasteurization of Mycobacterium paratuberculosis in whole milk. In: Chiodini RJ, Hines II ME, Collins MT (Eds). Proceedings of the Fifth International Colloquium on Paratuberculosis, 1997.

76. Ogura Y, Bonen DK, Inohara N, Nicolae DL, Chen FF, Ramos R, Britton H, Moran T, Karaliuskas R, Duerr RH, Achkar JP, Brant SR, Bayless TM, Kirschner BS, Hanauer $\mathrm{SB}$, Nunez G, Cho JH. A frameshift mutation in NOD2 associated with susceptibility to Crohn's disease. Nature 2001;411:603-606.

77. Hugot JP, Chamaillard M, Zouali H, Lesage S, Cezard JP, Belaiche J, Almer S, Tysk C, O’Morain CA, Gassull M, Binder V, Finkel Y, Cortot A, Modigliani R, Laurent-Puig P, Gower-Rousseau C, Macry J, Colombel JF, Sahbatou M, Thomas G. Association of NOD2 leucine-rich repeat variants with susceptibility to Crohn's disease. Nature 2001;411:599-603.

78. McGovern DP, Van Heel DA, Ahmad T, Jewell DP. NOD2 (CARD15), the first susceptibility gene for Crohn's disease. Gut 2001;49:752-754.

79. Judge T, Lichtenstein GR. The NOD2 gene and Crohn's disease: another triumph for molecular genetics. Gastroenterology 2002;122:826-828.

80. Ogura Y, Inohara N, Benito A, Chen FF, Yamaoka S, Nunez G. NOD2, a Nod1/Apaf-1 family member that is restricted to monocytes and activates NF-kappaB. J Biol Chem 2001;276:4812-4818.

81. Lesage S, Zouali H, Cezard JP, Colombel JF, Belaiche J, Almer S, Tysk C, O’Morain C, Gassull M, Binder V, Finkel Y, Modigliani R, Gower-Rousseau C, Macry J, Merlin F, Chamaillard M, Jannot AS, Thomas G, Hugot JP; EPWG-IBD Group; EPIMAD Group; GETAID Group. Card15/NOD2 mutational analysis and genotypephenotype correlation in 612 patients with inflammatory bowel disease. Am J Hum Genet 2002;70:845-857.

82. Inohara N, Ogura Y, Chen FF, Muto A, Nunez G. Human Nod1 confers responsiveness to bacterial lipopolysaccharides. J Biol Chem 2001;276:2551-2554.

83. Hampe J, Cuthbert A, Croucher PJ, Mirza MM, Mascheretti S, Fisher S, Frenzel H, King K, Hasselmeyer A, MacPherson AJ, Bridger S, van Deventer S, Forbes A, Nikolaus S, Lennard-Jones JE, Foelsch UR, Krawczak M, Lewis C, Schreiber S, Mathew CG. Association between insertion mutation in NOD2 gene and Crohn's disease in German and British populations. Lancet 2001;357:19251928.

84. Cuthbert AP, Fisher SA, Mirza MM, King K, Hampe J, Croucher PJ, Mascheretti S, Sanderson J, Forbes A, Mansfield J, Schreiber S, Lewis CM, Mathew CG. The contribution of NOD2 gene mutations to the risk and site of disease in inflammatory bowel disease.

Gastroenterology 2002;122:867-874. 
85. Ahmad T, Armuzzi A, Bunce M, Mulcahy-Hawes K,

Marshall SE, Orchard TR, Crawshaw J, Large O, de Silva

A, Cook JT, Barnardo M, Cullen S, Welsh KI, Jewell DP.

The molecular classification of the clinical manifestations of Crohn's disease. Gastroenterology 2002;122:854-866.

86. Sachar DB. Genomics and phenomics in Crohn's disease. Gastroenterology 2002;122:1161-1162.

87. Meresse B, Rutgeerts P, Malchow H, Dubucquoi S,

Dessaint JP, Cohard M, Colombel JF, Desreumaux P. Low ileal interleukin 10 concentrations are predictive of endoscopic recurrence in patients with Crohn's disease. Gut 2002;50:25-28.

88. Schreiber S. Monocytes or T cells in Crohn's disease: does IL-16 allow both to play at that game? Gut 2001;49:747748.

89. Glas J, Martin K, Brunnler G, Kopp R, Folwaczny C, Weiss EH, Albert ED. MICA, MICB and C1_4_1 polymorphism in Crohn's disease and ulcerative colitis. Tissue Antigens 2001;58:243-249. 